Special Issue of the 6th International Congress \& Exhibition (APMAS2016), Maslak, Istanbul, Turkey, June 1-3, 2016

\title{
Fabrication of Transparent Yttria Ceramics by Spark Plasma Sintering
}

\author{
E. KORKMAZ* AND F. SAHIN \\ Istanbul Technical University, Department of Metallurgical and Materials Engineering, \\ 34469 Maslak, Istanbul, Turkey
}

\begin{abstract}
Rapid densification of yttria $\left(\mathrm{Y}_{2} \mathrm{O}_{3}\right)$ ceramics without sintering aids via spark plasma sintering at relatively low temperature of $1300{ }^{\circ} \mathrm{C}$ for 40 minutes at two-step pressure profile, followed by post-annealing at $1050{ }^{\circ} \mathrm{C}$ for 6 hours in air was attempted. Effect of preload pressure on microstructure, Vickers hardness, fracture toughness and optical in-line transmittance was investigated. Densification during spark plasma sintering did not involve any phase transformation and all phases have shown cubic structure according to X-ray analysis. The highest hardness and fracture toughness value was recorded to be $7.60 \pm 0.18 \mathrm{GPa}$ and $1.16 \pm 0.07 \mathrm{MPam}^{1 / 2}$ with $10 \mathrm{MPa}$ preload and $100 \mathrm{MPa}$ final load. In addition to this, the highest transmittance with a value of $76.7 \%$ at a wavelength of $2000 \mathrm{~nm}$ was obtained when studied with $10 \mathrm{MPa}$ preload and $100 \mathrm{MPa}$ final load.
\end{abstract}

DOI: 10.12693 /APhysPolA.131.460

PACS/topics: 81.05.Je, 81.20.Ev, 81.40.Tv, 42.70.Hj

\section{Introduction}

Transparent polycrystalline yttria ceramics provides high potentials for optical applications, such as solidstate lasers [1-3], host materials for scintillators [4], missile domes [5] and light bulb envelopes [6] due to its high melting temperature around $2430^{\circ} \mathrm{C}$, high corrosion resistance, good thermal stability, high thermal conductivity [7], broad range of transparency from 0.2 to $8 \mu \mathrm{m}[8]$, high refractive index around 1.96 in the visible spectrum [9]. Spark plasma sintering (SPS) method is very effective for restraining grain growth, due to the possibility of full densification of ceramic powders within short time at relatively low temperatures [10]. Zhang et al. [4] have studied high-pressure spark plasma sintering of yttria and have achieved the transparency level of single crystal yttria, but as it is not feasible to work with such high pressures, moderate pressures are studied more often [7, 11]. Wang et al. [12] have studied the influence of the SPS pressure profile on transparency of $\mathrm{MgAl}_{2} \mathrm{O}_{4}$ ceramics, however it is the first time when this method is applied to yttria ceramics.

We have focused on producing high-quality, finegrained transparent yttria ceramics by using SPS with three-step heating regime $\left(100^{\circ} \mathrm{C} / \mathrm{min}, 25^{\circ} \mathrm{C} / \mathrm{min}\right.$, $10^{\circ} \mathrm{C} / \mathrm{min}$ ) and moderate pressure without any sintering aids. A two-step pressure profile was emphasized to analyze the effect of preload pressure on the final optical and mechanical properties of this ceramic.

\section{Materials and methods}

$\mathrm{Y}_{2} \mathrm{O}_{3}$ powder $(99.999 \%$ purity, American Elements, USA) with a manufacturer-determined average particle size of $90 \mathrm{~nm}$ was used as starting powder. The asreceived $\mathrm{Y}_{2} \mathrm{O}_{3}$ powder was ball milled for $12 \mathrm{~h}$ in ethanol

*corresponding author; e-mail: korkmaz@itu.edu.tr using zirconia balls and dried at $100{ }^{\circ} \mathrm{C}$ in an oven for $24 \mathrm{~h}$. The granulated powder was sieved through a 200mesh screen, calcined at $1000^{\circ} \mathrm{C}$ in air for $2 \mathrm{~h}$. The calcined powder was loaded into a graphite die with a $50 \mathrm{~mm}$ inner diameter.

A graphite sheet was inserted between the punches and mould, and the graphite mould was covered with carbon blanket heat insulators. Samples were sintered using a SPS apparatus (SPS-7.40MK-VII, SPS Syntex Inc. Japan) with different preload pressures of 10-50 MPa. Pressure was increased to $100 \mathrm{MPa}$ at $1000^{\circ} \mathrm{C}$ and was kept constant during sintering and cooling. The sintering temperature was increased in a heating regime of $100^{\circ} \mathrm{C} / \mathrm{min}$ between room temperature and $600{ }^{\circ} \mathrm{C}$, $25^{\circ} \mathrm{C} / \mathrm{min}$ between $600^{\circ} \mathrm{C}$ and $1000^{\circ} \mathrm{C}$, held at $1000^{\circ} \mathrm{C}$ for 5 minutes, heated at $10^{\circ} \mathrm{C} / \mathrm{min}$ between $1000^{\circ} \mathrm{C}$ and sintering temperature of $1300^{\circ} \mathrm{C}$, soaked 40 minutes at sintering temperature. The process temperature was measured by an optical pyrometer focused on the surface of the die. The sintered discs were sand blasted and annealed at $1050^{\circ} \mathrm{C}$ for 6 hours in air. The bulk densities of the sintered bodies were measured by the Archimedes method in distilled water. The crystal phases were identified by X-ray diffractometry (XRD, RAD-2C, Rigaku Corp., Japan) in $2 \theta$ range of $5-90^{\circ}$, using graphite monochromatic $\mathrm{CuK}_{\alpha}$ radiation.

Samples thicknesses were reduced to $\sim 0.5 \mathrm{~mm}$. Then samples were mirror-polished by $9 \mu \mathrm{m}, 3 \mu \mathrm{m}$ and $1 \mu \mathrm{m}$ diamond slurries, and in-line transparency values were measured using Agilent UV-Vis spectrophotometer.

Vickers hardness $\left(H_{\mathrm{V}}\right)$ and fracture toughness $\left(K_{\mathrm{IC}}\right)$ values were measured using a Vickers diamond indenter (Struers, Duramin A300) at a load of 9.8 N.

The polished sample surfaces were thermally etched in air for 45 minutes at $1100^{\circ} \mathrm{C}$ and microstructures of the specimens were observed using scanning electron microscopy (SEM, Model JSM 7000F, JEOL). 


\section{Results}

Figure 1 shows XRD patterns of SPSed $\mathrm{Y}_{2} \mathrm{O}_{3}$ ceramic samples, which were identified as those of single $\mathrm{Y}_{2} \mathrm{O}_{3}$, all indexed as cubic according to JCPDS no. 41-1105. All three samples have shown the same pattern and thus densification during SPS did not involve any phase transformation.

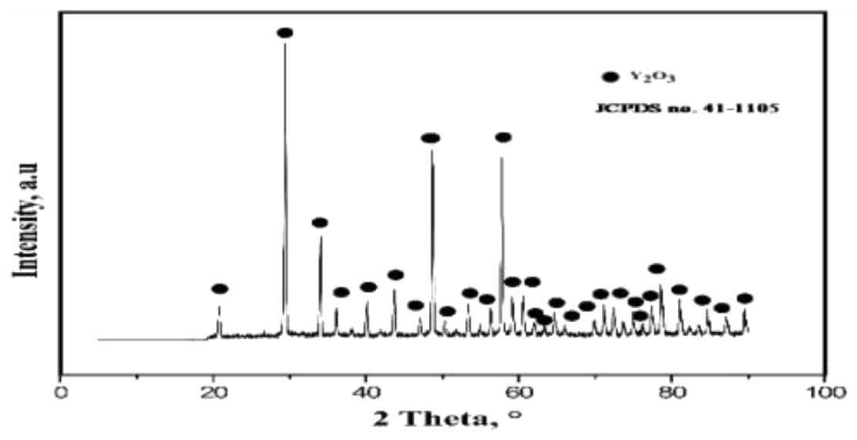

Fig. 1. XRD patterns of $\mathrm{Y}_{2} \mathrm{O}_{3}$ ceramics, spark plasma sintered at $1300^{\circ} \mathrm{C}$ for 40 minutes.

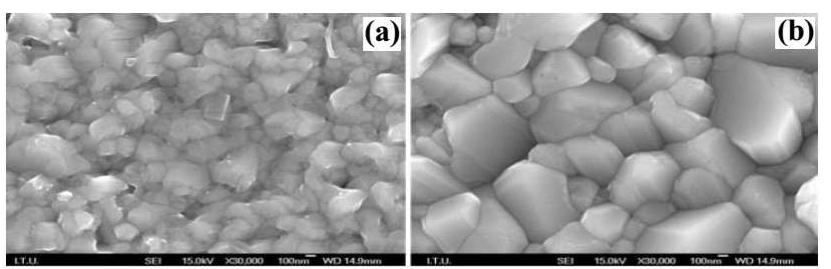

Fig. 2. Scanning electron micrographs of SPSed $\mathrm{Y}_{2} \mathrm{O}_{3}$ samples with (a) $10 \mathrm{MPa}$ preload and (b) $50 \mathrm{MPa}$ preload.

Figure 2 reveals that the exaggerated grain coarsening was dominant when applied preload was increased from 10 to $50 \mathrm{MPa}$. Relative density and average grain size values are given in Table I and in Fig. 3. Highest relative density of $99.4 \%$ was achieved with $10 \mathrm{MPa}$ preload, while very close values were obtained with 30 and $50 \mathrm{MPa}$.

\section{TABLE I}

Calculated relative density and average grain size results of sintered $\mathrm{Y}_{2} \mathrm{O}_{3}$ samples.

\begin{tabular}{c|c|c|c|c}
\hline \hline $\begin{array}{c}\text { Sample } \\
\text { name }\end{array}$ & $\begin{array}{c}\text { Preload } \\
{[\mathrm{MPa}]}\end{array}$ & $\begin{array}{c}\text { Final } \\
\text { load } \\
{[\mathrm{MPa}]}\end{array}$ & $\begin{array}{c}\text { Relative } \\
\text { density } \\
{[\%]}\end{array}$ & $\begin{array}{c}\text { Avarage } \\
\text { grain size } \\
{[\mathrm{nm}]}\end{array}$ \\
\hline P10 & 10 & 100 & 99.4 & $260 \pm 15$ \\
P30 & 30 & 100 & 98.8 & $320 \pm 10$ \\
P50 & 50 & 100 & 98.7 & $450 \pm 25$
\end{tabular}

Table II shows measured hardness, fracture toughness and in-line transmission results. The highest hardness value of $8.32 \pm 0.18 \mathrm{GPa}$ was recorded with $10 \mathrm{MPa}$ preload, as the specimen had the lowest average grain size value. Transparency value has decreased dramatically to $51.1 \%$ when the preload pressure was increased to $50 \mathrm{MPa}$.

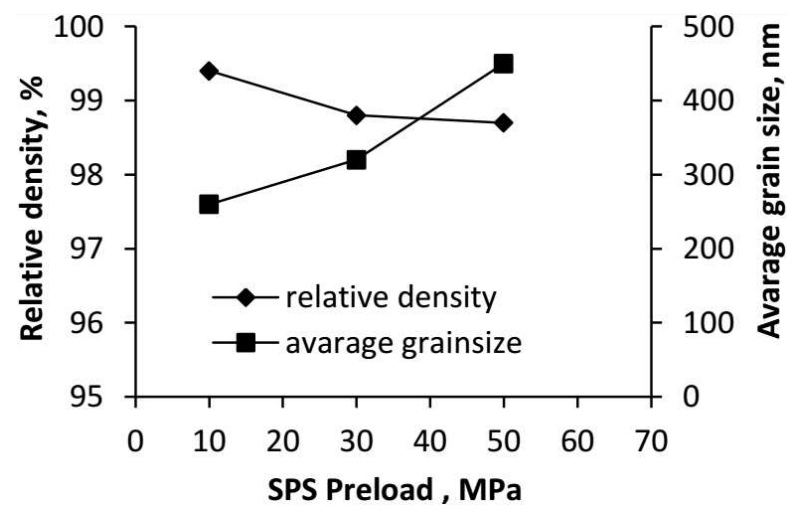

Fig. 3. Effect of SPS preload value on relative density and average grain size of SPSed $\mathrm{Y}_{2} \mathrm{O}_{3}$ samples.

TABLE II

Hardness $H_{\mathrm{V}}$, fracture toughness $K_{\mathrm{IC}}$ and in-line transmission ( $\mathrm{T}$ ) results of sintered $\mathrm{Y}_{2} \mathrm{O}_{3}$ samples.

\begin{tabular}{c|c|c|c}
\hline \hline Sample name & $H_{\mathrm{V}}[\mathrm{GPa}]$ & $K_{\mathrm{IC}}\left[\mathrm{MPa} \mathrm{m}^{1 / 2}\right]$ & $\mathrm{T}[\%]$ \\
\hline P10 & $8.32 \pm 0.18$ & $1.25 \pm 0.07$ & 76.7 \\
P30 & $7.56 \pm 0.16$ & $1.20 \pm 0.05$ & 70.2 \\
P50 & $7.01 \pm 0.20$ & $1.14 \pm 0.04$ & 51.1
\end{tabular}

Highest transparency with a value of $76.7 \%$ at $2000 \mathrm{~nm}$ was achieved when studied with $10 \mathrm{MPa}$ preload. Transparency value has decreased gradually with the increasing preload pressure, as indicated in Fig. 4. Decrease in transparency can be due to the disharmony of grain boundary mobility and pore removal mobility. When higher preload pressures were applied, grain boundary mobility had increased so much that pores could not reach the grain boundaries. As a result they were captured in grains.

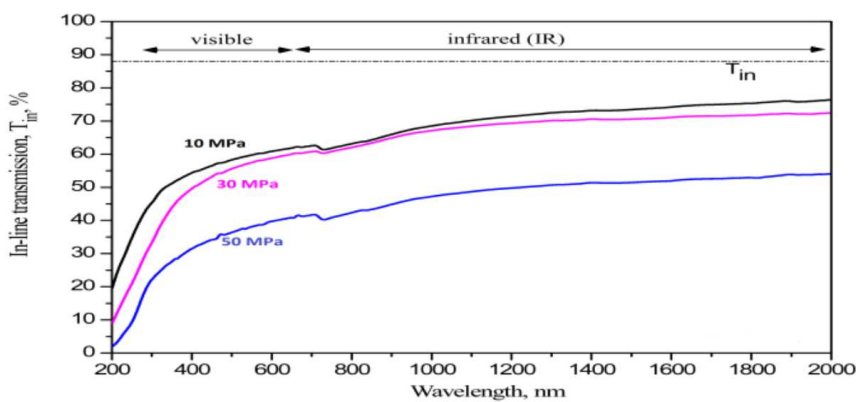

Fig. 4. In-line transmission versus wavelength for samples preloaded with different pressures.

\section{Conclusions}

$\mathrm{Y}_{2} \mathrm{O}_{3}$ ceramics with relative densities greater than $98 \%$ and grain sizes between $260-450 \mathrm{~nm}$ were obtained by spark plasma sintering technique. Samples of $8.32 \pm$ $0.18 \mathrm{GPa}$ Vickers hardness and $1.25 \pm 0.07 \mathrm{MPa} \mathrm{m}^{1 / 2}$ were achieved using $10 \mathrm{MPa}$ SPS preload pressure, which is in accordance with the reported $1.0-1.5 \mathrm{MPa} \mathrm{m}^{1 / 2}$ range 
and 7-9 GPa range [11]. The highest in-line transparency value was recorded to be $76.7 \%$, at a wavelength of $2000 \mathrm{~nm}$, when studied with $10 \mathrm{MPa}$ preload and $100 \mathrm{MPa}$ final load, although this sample have had the smallest grains. High transmittance results of lower preloaded samples can be attributed to the high relative density of the specimen. In order to achieve such high values, methods to restrain grain growth, such as addition of sintering additives, can be studied.

\section{References}

[1] X. Hou, S. Zhou, T. Jia, H. Lin, H. Teng, J. Lumin. 131, 1953 (2011).

[2] J.R. Lu, J.H. Lu, T. Murai, K. Takaichi, T. Uematsu, K. Ueda, H. Yagi, T. Yanagitani, A.A. Kaminskii, Japn. J. Appl. Phys. Lett. 40, L1277 (2001).

[3] L. Zhang, W. Pan, J. Am. Ceram. Soc. 98, 3326 (2015).

[4] H. Zhang, B.N. Kim, K. Morita, H. Yoshida, K. Hiraga, Y. Sakka, J. Am. Ceram. Soc. 94, 3206 (2011).
[5] D.C. Harris, Infrar. Phys. Technol. 39, 185 (1998).

[6] L. Huang, W. Yao, J. Liu, A.K. Mukherjee, J.M. Schoenung, Scripta Mater. 75, 18 (2014).

[7] S.F. Wang, J. Zhang, D.W. Luo, F. Gua, D.Y. Tang, Z.L. Dong, G.E.B. Tan, W.X. Que, T.S. Zhang, S. Li, L.B. Kong, Progr. Solid State Chem. 41, 20 (2013).

[8] J. Mouzon, A. Maitre, L. Frisk, N. Lehto, M. Oden, J. Eur. Ceram. Soc. 29, 311 (2009).

[9] M.G. Chapman, M.R. Marchewka, S.A. Roberts, J.M. Schmitt, C. McMillen, C.J. Kucera, T.A. DeVol, J. Ballato, L.G. Jacobsohn, J. Lumin. 165, 56 (2015).

[10] C. Greskovi, J.P. Chernoch, J. Appl. Phys. 44, 4599 (1973).

[11] L. Ana, A. Ito, T. Goto, J. Eur. Ceram. Soc. 32, 1035 (2012)

[12] C. Wang, Z. Zhaob, Scripta Mater. 61, 193 (2009). 